\title{
Proton-exchange-membrane fuel cells durability evaluated by load-on/off cycling
}

\author{
G.J.M. Janssen \\ E.F. Sitters \\ A. Pfrang \\ Published in the Journal of Power Sources 191 (2009) 501 - 509)
}





\title{
Proton-exchange-membrane fuel cells durability evaluated by load-on/off cycling
}

\author{
G.J.M. Janssen ${ }^{a}$,* E.F. Sitters ${ }^{a}$, A. Pfrang ${ }^{b}$ \\ a Department of Hydrogen and Clean Fossil Fuels, Energy research Centre of the Netherlands ECN, P.O. Box 1, 1755 ZG Petten, The Netherlands \\ ${ }^{\mathrm{b}}$ European Commission, Joint Research Centre, Institute for Energy, P.O. Box 2, 1755 ZG Petten, The Netherlands
}

\section{A R T I C L E I N F O}

\section{Article history:}

Received 30 June 2008

Received in revised form 3 November 2008

Accepted 8 February 2009

Available online 20 February 2009

\section{Keywords:}

Proton-exchange-membrane fuel cell

Cathode active layer

Durability

Transport properties

Accelerated stress test

\begin{abstract}
A B S T R A C T
Load-on/off cycles at $80^{\circ} \mathrm{C}$, with near-saturated $\mathrm{H}_{2}$ and air at ambient pressure were applied to investigate the durability of several types of membrane-electrode-assemblies (MEAs) for protonexchange-membrane fuel cells (PEMFC). The ohmic resistance, $\mathrm{H}_{2}$ cross-over, electrochemically active surface area (ECSA), protonic resistance of the cathode as well as the performances with $\mathrm{H}_{2} /$ air and $\mathrm{H}_{2} / \mathrm{O}_{2}$ were measured at regular intervals. These data enabled a breakdown of the increase in cell voltage losses upon cycling. Increase of kinetic losses was found in all MEAs but significant differences were obtained for the transport losses in the cathode catalyst layer, which either had a small or a substantial contribution to the overall voltage decay, depending on the carbon type and ionomer loading. Membrane degradation did not contribute significantly in these tests.
\end{abstract}

(c) 2009 Elsevier B.V. All rights reserved.

\section{Introduction}

In recent years it has become clear that before large-scale introduction of the proton-exchange-membrane fuel cell (PEMFC) becomes feasible, its durability should be significantly improved $[1,2]$. This fact has motivated many studies into degradation mechanisms of PEMFC components and conditions accelerating the degradation. Two reviews summarize the current insights [3,4]. One of the findings is that for a PEMFC load cycling, which is inherent to automotive applications, is much more detrimental than stationary operation. The cycling of the potential accelerates the dissolution of the platinum catalyst in the electrodes [5]. Exposure to $\mathrm{H}_{2}$ and air of the membrane-electrode-assembly (MEA) during open-circuit-voltage $(\mathrm{OCV})$ conditions enhances chemical membrane degradation [6-10]. The water content in the MEA will fluctuate with the current leading to mechanical degradation of the membrane. Moreover, catalyst dissolution and membrane degradation may reinforce each other [11].

In the current literature less attention is paid to the changes of transport losses in the electrodes, although in a study of PEMFC degradation under stationary conditions Cleghorn et al. already showed that increase of transport losses in the catalyst layer rather than membrane degradation and electrocatalyst degradation were

\footnotetext{
* Corresponding author. Tel.: +31 22456 4803; fax: +31 224568489.

E-mail addresses: janssen@ecn.nl (G.J.M. Janssen), sitters@ecn.nl (E.F. Sitters), andreas.pfrang@ec.europa.eu (A. Pfrang).
}

the principal source for performance decay [12]. A similar result was reported by Xie et al. [13]. Accelerated stress test protocols aiming at the evaluation of durability of separate components such as electrocatalysts, catalyst supports and membranes have been developed which involve potential cycling, potential hold or OCV hold [2]. However, these protocols focus on one degradation mechanism and they seem less suited to study degradation and its effects on processes in the catalyst layer. Since this layer contains supported catalyst as well as an ionomer phase, several mechanisms act concurrently. Repetitive load-on/off cycles might be more effective in establishing the extent of degradation in this layer provided that they are carried out with extensive diagnosis in order to make a breakdown of the voltage decay in terms related to the various components.

Lee et al. recently reported on the effect of load-on/off cycles on MEAs [14]. They observed a considerable membrane thinning after 50 load-on/off cycles, as well decay of the OCV and cell voltage. However, a breakdown of the voltage losses was not presented. The effects were mitigated when the anode was purged with air instead of $\mathrm{H}_{2}$ during load-off periods. In the present work the type of load cycles that had the more severe consequences, i.e. with $\mathrm{H}_{2}$ at the anode and air at the cathode flowing during load-off periods, were applied. Note, that this excludes the occurrence of high potentials at the cathode which may arise in a realistic system when during OCV the $\mathrm{H}_{2}$ flow is stopped and air leaches in, giving rise to an air/hydrogen front [15]. An extensive set of in situ diagnostics was applied to enable the breakdown of the cell voltage losses. 


\begin{tabular}{|c|c|}
\hline \multicolumn{2}{|c|}{ Nomenclature } \\
\hline$b$ & $\begin{array}{l}\text { Tafel slope of the oxygen reduction electro reaction } \\
\left(\mathrm{mV} \mathrm{dec}^{-1}\right)\end{array}$ \\
\hline$C_{\mathrm{dl}}$ & double layer capacitance of the electrode $\left(\mathrm{F} \mathrm{cm}^{-2}\right)$ \\
\hline$E^{0}$ & thermodynamic open circuit potential (V) \\
\hline ECSA & electrochemically active surface area $\left(\mathrm{m}^{2} \mathrm{~g}_{\mathrm{Pt}}{ }^{-1}\right)$ \\
\hline$F$ & Faraday constant $\left(96485 \mathrm{C} \mathrm{mol}^{-1}\right)$ \\
\hline$i_{\mathrm{m}}$ & mass activity of the platinum $\left(\mathrm{Ag}^{-1}\right)$ \\
\hline$i_{\mathrm{o}}$ & exchange current density parameter $\left(\mathrm{A} \mathrm{cm}^{-2}\right)$ \\
\hline$i_{\mathrm{s}}$ & specific activity of the platinum $\left(\mu \mathrm{Acm}_{\mathrm{Pt}}{ }^{-2}\right)$ \\
\hline$i_{x}$ & $\begin{array}{l}\text { current density equivalent to the hydrogen cross- } \\
\text { over }\left(\mathrm{Acm}^{-2}\right)\end{array}$ \\
\hline j & current density in the cell $\left(\mathrm{Acm}^{-2}\right)$ \\
\hline$m_{\mathrm{Pt}}$ & platinum content of the electrode $\left(\mathrm{mg} \mathrm{cm}^{-2}\right)$ \\
\hline$p \mathrm{H}_{2}, \quad p$ & $\begin{array}{l}\mathrm{O}_{2} \text { hydrogen/oxygen partial pressure at the } \\
\text { anode/cathode (bar) }\end{array}$ \\
\hline$p^{0}$ & reference pressure ( 1 bar $)$ \\
\hline$R$ & gas constant $\left(8.31 \mathrm{~J} \mathrm{~mol}^{-1} \mathrm{~K}^{-1}\right)$ \\
\hline$R_{\mathrm{hf}}$ & ohmic resistance of the cell $\left(\Omega \mathrm{cm}^{2}\right)$ \\
\hline$R_{\mathrm{p}}$ & protonic resistance in electrode $\left(\Omega \mathrm{cm}^{2}\right)$ \\
\hline$T$ & cell temperature (K) \\
\hline$V_{\text {cell }}$ & cell voltage $(\mathrm{V})$ \\
\hline$V_{\mathrm{IR} \text {-corr }}$ & cell voltage corrected for ohmic losses (V) \\
\hline & impedance in the high frequency range $\left(\Omega \mathrm{cm}^{2}\right)$ \\
\hline \multicolumn{2}{|c|}{ Greek letters } \\
\hline$\gamma$ & reaction order of the ORR \\
\hline$\eta$ & cell voltage loss $(\mathrm{V})$ \\
\hline$\eta_{\mathrm{ORR}}$ & overpotential related to kinetics of the ORR (V) \\
\hline$\eta_{\text {transport }}$ & $\begin{array}{l}\text { overpotential related to mass transport in the cath- } \\
\text { ode }(\mathrm{V})\end{array}$ \\
\hline & ohmic loss (V) \\
\hline & angular frequency $\left(\mathrm{s}^{-1}\right)$ \\
\hline
\end{tabular}

Several types of home-made MEAs consisting of commercial materials were studied in this work. The MEAs contained as catalyst Hispec ${ }^{\circledR} 4000$ or Hispec ${ }^{\circledR} 9100$, both developed by Johnson Matthey. The ionomer content in the electrodes was varied. The membranes considered were all based upon Nafion ${ }^{\circledR} 1100$ and comprised the extrusion cast N112, as well as the recast membranes NRE211 and NRE212CS, the latter of which contained chemically stabilized Nafion.

\section{Experimental}

\subsection{Manufacturing of MEAs}

An ink was made consisting of commercial Pt/C powder dispersed in 1,2-propanediol to which a Nafion ${ }^{\circledR}$ solution ( $25 \mathrm{wt} \%$ in 1,2-propanediol) was added and a small amount of stabilizer. Three electrode types were made. In the first type the Pt/C was Hispec 4000 ( 38 wt\% Pt on Vulcan XC-72R, obtained from Alfa Aesar) and the dry electrode material contained $30 \mathrm{wt} \%$ Nafion, resulting in a Nafion:carbon weight $(\mathrm{N}: \mathrm{C})$ ratio of 0.7 . The second type was on the basis of Hispec 9100 (57 wt\% Pt on high surface area carbon black, Alfa Aesar), and contained 20 wt\% Nafion in the dry electrode, corresponding to a $\mathrm{N}: \mathrm{C}$ ratio of 0.55 . The third type was similar to the second type but with an increased Nafion loading of $23 \mathrm{wt} \%$ which corresponds to a $\mathrm{N}: \mathrm{C}$ ratio of 0.7 .

The ink was then screen printed on Sigracet ${ }^{\circledR}$ gas diffusion layer (GDL) 31 BC purchased from SGL Carbon, followed by a drying step. The Pt loading in the Hispec 4000 electrodes was $0.40 \pm 0.04$ and $0.39 \pm 0.03$ and $0.40 \pm 0.1 \mathrm{mg} \mathrm{cm}^{-2}$ in both types of Hispec 9100

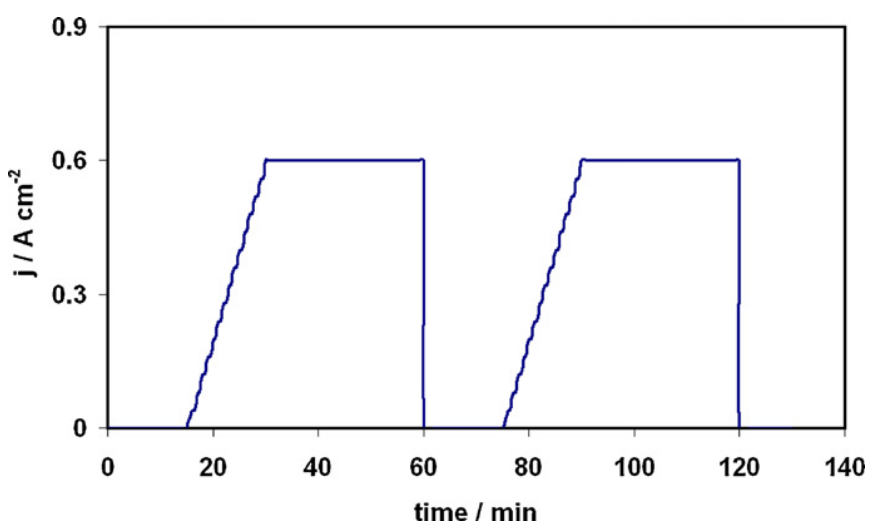

Fig. 1. The load profile for the load-on/off cycles in this study: $\mathrm{H}_{2} /$ air are supplied during $15 \mathrm{~min}$ without load, next the load is increased in steps of $0.04 \mathrm{~A} \mathrm{~cm}^{-2}$ during $15 \mathrm{~min}$ ( $\mathrm{H}_{2} /$ air), followed by operation during $30 \mathrm{~min}$ at maximum load, also with $\mathrm{H}_{2}$ /air, and then the load is switched off again. Two cycles are shown here.

electrodes, respectively. On the electrode a solution of $10 \%$ Nafion in water/3\% butanol was applied, resulting in an additional Nafion loading in the order of $0.03 \mathrm{mg} \mathrm{cm}^{-2}$, followed by another drying step. With the first as well as the second electrode type five MEAs were made by hot-pressing two (similar) electrodes on one of the following membranes from DuPont: N112 (in duplo), NRE211 (in duplo) and N212CS. With third type of electrode two MEAs with a N112 membrane were made. The geometric surface area of the MEAs was $7 \mathrm{~cm}^{2}$. The MEAs were pressed at $130{ }^{\circ} \mathrm{C}$ and 40 bar during $90 \mathrm{~s}$

\subsection{MEA operation}

The MEAs were clamped between two graphite blocks containing a serpentine flow channel and mounted into a test station. Operation was at ambient pressure with $\mathrm{H}_{2}$ /air conditions with respective stoichiometry of 1.5 and 2 . Gases were humidified by leading them over a membrane in contact with liquid water at cell temperature. At high flow rates (i.e. high current density) and at high cell temperature $\left(80^{\circ} \mathrm{C}\right)$ this may not always lead to $100 \%$ humidification, but to dew points between 73 and $77^{\circ} \mathrm{C}$ The cell was started up at $65^{\circ} \mathrm{C}$, with constant current density $0.4 \mathrm{~A} \mathrm{~cm}^{-2}$. After $50 \mathrm{~h}$ the temperature was increased to at $80^{\circ} \mathrm{C}$. Normal operation was at this temperature with constant current density $0.4 \mathrm{~A} \mathrm{~cm}^{-2}$. During operation $30 \mathrm{~s}$ of OCV conditions were included every hour.

\subsection{Load-on/off cycling}

The load cycle employed in this study consisted of three steps, as shown in Fig. 1. In step 1 hydrogen and air were supplied to the anode and the cathode, respectively, for $15 \mathrm{~min}$ without applying the load; in step 2, the load was increased from 0 to $0.6 \mathrm{Acm}^{-2}$ in steps of $0.04 \mathrm{~A} \mathrm{~cm}^{-2} \mathrm{~min}^{-1}$; and in step 3, the cell was operated at the constant load of $0.6 \mathrm{~A} \mathrm{~cm}^{-2}$ during $30 \mathrm{~min}$, after which the load was removed. After 10 such cycles the cell underwent a set of diagnostics and then was put at the conditions of normal operation $\left(0.4 \mathrm{~A} \mathrm{~cm}^{-2}\right)$. The total testing time was in the order of $600 \mathrm{~h}$. Depending on the type of MEA, the cell voltage minimum was between 0.6 and $0.45 \mathrm{~V}$.

\subsection{Diagnostics}

Before the cycling and after each set of 10 cycles following diagnostics were carried out: 
1. Recording of a voltage-current density $(V-j)$ curve with $\mathrm{H}_{2}$ /air, respective stoichiometry 1.5 and 2 , by increasing $j$ every $30 \mathrm{~s}$ until a cell voltage of $0.1 \mathrm{~V}$ was reached.

2. Recording of a $V-j$ curve with $\mathrm{H}_{2}$ /oxygen, respective stoichiometry 1.5 and 9.5 increasing $j$ every $30 \mathrm{~s}$ up to $j=2.2 \mathrm{~A} \mathrm{~cm}^{-2}$.

3. An impedance spectrum with the cathode operating under $\mathrm{O}_{2}$ as working electrode and the anode $\left(\mathrm{H}_{2}\right)$ as reference and counter electrode. The impedance spectra were recorded with a IM6e Zahner impedance spectrometer, galvanostatically at $50 \mathrm{mAcm}^{-2}$, from 1 to $100 \mathrm{kHz}$ and from $100 \mathrm{kHz}$ to $1 \mathrm{~Hz}$, with 10 points per decade.

4. A cyclic voltammogram $\left(\mathrm{H}_{2} / \mathrm{N}_{2}\right)$ between 0.06 and $0.75 \mathrm{~V}$ with scanning rate $50 \mathrm{mV} \mathrm{s}^{-1}$ to determine the electrochemically active surface area (ECSA) and double layer capacitance of the cathode.

5. An electrochemical measurement of the hydrogen cross-over, with humidified $\mathrm{H}_{2}$ at the anode and humidified $\mathrm{N}_{2}$ at the cathode. These experiments were carried out at 1.5 bar to avoid leaching in of air. The potential of the cathode was set at $0.45 \mathrm{~V}$ with respect to the anode.

\subsection{Post-test analysis}

Post test some of the MEAs were studied with a JEOL-JSM-6330F scanning electron microscope (SEM). The MEAs were broken in liquid nitrogen and from SEM micrographs of the cross-section the thickness of the electrodes and membranes was measured. In addition a sample of powder was scraped with a razor blade from the cathode catalyst layer of used MEAs. Both these powders and pristine Hispec 4000 and Hispec 9100 were immersed in ethanol to disperse the powder particles. The suspensions were then deposited on a copper grid for transmission electron microscope (TEM) analysis, TEM analysis, using a Philips TECNAI 20 transmission electron microscope operated at $200 \mathrm{kV}$ with a $\mathrm{LaB}_{6}$ filament.

\section{Theory}

\subsection{Break-down of cell voltage losses}

The cell voltage of a PEMFC is reduced compared to the theoretical Nernst voltage $\left(E^{0}\right)$ by ohmic losses, cathode losses and anode losses. It is often assumed that in a PEMFC fed on pure $\mathrm{H}_{2}$, the anode losses can be neglected [16,17]. The cell voltage is then written as [16] (see list of symbols for definition of symbols):

$V_{\text {cell }}(j)=E^{0}-\eta_{\Omega}(j)-\eta_{\text {ORR }}(j)-\eta_{\text {transport }}(j)$

The Nernst potential $E^{0}$ depends on the temperature and gas pressures according to [18]:

$$
\begin{aligned}
E^{0}= & 1.229 V-0.00085 \frac{V}{K}(T-298.15) \\
& +\frac{R T}{4 F} 2.303 \log \left[\left(\frac{p \mathrm{H}_{2}}{p^{\circ}}\right)^{2}\left(\frac{p \mathrm{O}_{2}}{p^{\circ}}\right)\right]
\end{aligned}
$$

The second term on the right hand side in Eq. (1) denotes the ohmic losses $\eta_{\Omega}=j R_{\mathrm{hf}}$ with $R_{\mathrm{hf}}$ the ohmic resistance of the cell. The third and fourth term on the right hand side of Eq. (1) refer to the kinetic and the transport part of the cathode losses, respectively. The kinetic losses depend on the oxygen partial pressure [16,19]:

$\eta_{\mathrm{ORR}}(j)=b \log \frac{j+i_{x}}{i_{0}\left(p \mathrm{O}_{2} / p^{o}\right)^{\gamma}}$

Here $b$ is kinetic Tafel slope, with theoretical value $R T / F$, and $\gamma$ the reaction order of the oxygen reduction reaction (ORR). The $i_{0}$ is an effective exchange current density that incorporates the activity of the catalyst for the ORR as well as the ECSA.

For the transport losses no rigorous analytical expression is available. However, they will include proton transport losses and oxygen diffusion losses, and therefore depend on the proton resistance of the cathode $R_{\mathrm{p}}$, on the oxygen partial pressure, on the permeability of the catalyst layer and on the permeability of the GDL. The property giving the most information on transport losses is probably the oxygen gain, i.e. the difference in cell voltage between operation with oxygen and air, at the same current density [20,21]:

$V_{\text {oxgain }}(j)=V_{\text {cell }}^{\mathrm{O}_{2}}(j)-V_{\text {cell }}^{\text {air }}(j)$

By further substitution of Eqs (1)-(3) into Eq. (4) it can be derived that $V_{\text {oxgain }}(j)$ can also be written as:

$$
\begin{aligned}
V_{\text {oxgain }}(j)= & \left(\frac{R T}{4 F} 2.303+\gamma b\right) \log \frac{p \mathrm{O}_{2}^{\mathrm{O}_{2}}}{p \mathrm{O}_{2}^{\text {air }}} \\
& -\left(\eta_{\text {transport }}^{\mathrm{O}_{2}}(j)-\eta_{\text {transport }}^{\text {air }}(j)\right)
\end{aligned}
$$

The first term on the right hand side of Eq. (5) is independent of the current density when the cell is operated at fixed stoichiometry, and with $b=70 \mathrm{mV} \mathrm{dec}^{-1}$ and $\gamma=0.5$ is the order of $40 \mathrm{mV}$ [20]. The transport losses for a cell operated with oxygen will be mainly due to proton transport losses [18,21-24]. When the cell is operated with air the oxygen partial pressure in the catalyst layer will be reduced compared to the value in the gas channel due to diffusion through the GDL as well as due to diffusion in the catalyst layer. Proton transport losses are also included in $\eta_{\text {transport }}^{\text {air }}$ and it must be noted that they are not necessarily the same as in $\eta_{\text {transport }}^{\mathrm{O}_{2}}$. Only at low current density, when the cathode is essentially operating in the kinetic limit can the proton transport losses in both cases be approximated by $j R_{\mathrm{p}} / 2$ [21]. At high current density the contributions will differ as with oxygen the reaction will take place mostly at the membrane side to minimize transport losses, whereas with air operation the reaction may shift towards the GDL $[18,21,22,24]$. In the latter case oxygen transport losses are reduced at the expense of increased proton transport losses. This implies that the oxygen gain will increase with reduced permeability as well as with increased protonic resistance of the catalyst layer.

In Sections 3.2-3.4 it will be explained how the respective contributions and changes in them upon cycling are derived from the measured data.

\subsection{Ohmic losses}

The ohmic resistance $R_{\mathrm{hf}}$ was determined every 10 cycles from the high frequency (hf) intercept of the impedance spectrum with the real axis. The ohmic resistance includes contributions of cell hardware and GDLs as well as contact resistance, but also the protonic resistance of the membrane. The values are therefore expected to be dependent on the type of membrane, more specifically its thickness. The change in ohmic loss between cycle 0 and cycle $n$ can be calculated from:

$\Delta \eta_{\Omega}=j\left(R_{\mathrm{hf}}^{n}-R_{\mathrm{hf}}^{0}\right)$

\subsection{Kinetic losses}

Kinetic data were derived from the $V-j$ curves measured with $\mathrm{H}_{2} / \mathrm{O}_{2}$ corrected for the ohmic loss $j R_{\text {hf }}$ (see Section 3.2) At low current density transport losses can be neglected and use of Eqs. (1) and (3) would allow the determination of $b$ and $i_{0}$. However, because the determination of $i_{0}$ requires extrapolation of the measured data over several decades of the current density, it is commonly 
accepted to relate the kinetic activity to the performance at $0.9 \mathrm{~V}$, IR-corrected [25]:

$V_{\mathrm{IR}-\operatorname{corr}}(j)=0.9 V-b \log \left(\frac{j+i_{x}}{i_{\mathrm{s}} \mathrm{ECSAm}_{\mathrm{pt}}\left(\mathrm{pO}_{2} / p^{\circ}\right)^{0.75}\left(p \mathrm{H}_{2} / p^{\circ}\right)^{0.5}}\right)$

In this equation $m_{\mathrm{Pt}}$ is the Pt loading of the electrode (often expressed in $\mathrm{mg} \mathrm{cm}^{-2}$ ) and $i_{\mathrm{s}}$ the specific activity of the electrode catalyst, characterizing the catalytic activity of the Pt particles. The ECSA is the electrochemically active surface area of the Pt catalyst. The gas pressures are included to normalize the specific activity $i_{\mathrm{s}}$ to 1 bar oxygen pressure and 1 bar hydrogen pressure, according to the procedure outlined by Neyerlin et al. [25]. This includes both a correction for the actual oxygen pressure on the kinetics (assuming a reaction order $\gamma=0.5$ ) as well as a correction for the thermodynamic effect of the gas pressures on the Nernst potential. Eq. (7) was used to determine the specific activity $i_{\mathrm{s}}$ and the effective Tafel slope $b$ from the low current density $\left(<100 \mathrm{~mA} \mathrm{~cm}^{-2}\right)$ region of the $V-j$ curves measured every 10 cycles with $\mathrm{H}_{2} / \mathrm{O}_{2}$. The value for the ECSA was determined from the hydrogen desorption area from cyclic voltammograms also measured every 10 cycles.

The specific activity characterizes the intrinsic activity of the catalyst, whereas the catalytic activity of the electrode is represented by the mass activity $i_{\mathrm{m}}$, which also includes the effect of ECSA, i.e. $i_{\mathrm{m}}=i_{\mathrm{s}} \times$ ECSA. With this definition of $i_{\mathrm{m}}$ and from Eqs. (1), (3) and (7) it can be derived that the $i_{0}$ and $i_{\mathrm{m}}$ are related by a fixed proportionality constant as long as temperature and the partial oxygen and hydrogen pressures are constant. Hence it follows that the reduction from an initial value of the mass activity from $i_{\mathrm{m}}^{0}$ at 0 cycles to $i_{\mathrm{m}}^{\mathrm{n}}$ at $n$ cycles should result in an increase of the $\eta_{\mathrm{ORR}}$ given by:

$\Delta \eta_{\mathrm{ORR}}=b \log \frac{i_{m}^{0}}{i_{m}^{n}}$

It must be noted that the change in kinetic losses does not depend on the oxygen partial pressure, i.e. the change in kinetic loss is the same when the cell is operated under oxygen and when it is operated under air.

\subsection{Transport losses}

The protonic resistance of the catalyst layer $R_{\mathrm{p}}$ was derived from the hf region of the impedance spectrum according to [26-28]:

$Z_{t}^{\mathrm{hf}}(\omega)=R_{\mathrm{hf}}+\sqrt{\frac{R_{p}}{C_{\mathrm{dl}}}} \omega^{-1 / 2} \frac{\sqrt{2}}{2}(1-i)$

Eq. (9) implies that the hf part of the impedance Nyquist plot has a so-called $45^{\circ}$ region, i.e. a region where the Nyquist plot is a straight line with a $45^{\circ}$ angle to the real axis. This part of the spectrum usually corresponds to frequencies between 1 and $10 \mathrm{kHz}$. At higher frequency the impedance is dominated by inductance effects and at lower frequency by the charge transfer reaction [21,28]. Points belonging to the $45^{\circ}$ region were selected and a fit of Eq. (9) was made. The values for the double layer capacitance $C_{\mathrm{dl}}$ were obtained from the cyclic voltammogram data.

As stated in Section 3.4 a rigorous expression reflecting the role of $R_{\mathrm{p}}$ in transport losses is not available. However, it may be expected that changes in $R_{\mathrm{p}}$ dominate changes in $\Delta \eta_{\text {transport }}^{\mathrm{O}_{2}}$ that can be calculated from:

$\Delta \eta^{\mathrm{O}_{2}}(j)=\Delta \eta_{\Omega}(j)+\Delta \eta_{\mathrm{ORR}}(j)+\Delta \eta_{\text {transport }}^{\mathrm{O}_{2}}(j)$

with $\Delta \eta^{\mathrm{O}_{2}}$ being the increase in cell voltage losses after cycling for operation under $\mathrm{O}_{2}$ :

$\Delta \eta^{\mathrm{O}_{2}}(j)=V_{\text {cell }}^{\mathrm{O}_{2}, 0}(j)-V_{\text {cell }}^{\mathrm{O}_{2}, n}(j)$
Table 1

The high frequency resistance $R_{\mathrm{hf}}$ and the cross-over current density $i_{x}$ measured before cycling (at $80^{\circ} \mathrm{C}$ ). Average values with corresponding standard deviations for each membrane type are listed. For each type of membrane the number of MEAs used to calculate the average is in given parentheses. The $i_{x}$ values refer to $1 \mathrm{bar} \mathrm{H}_{2}$

\begin{tabular}{llcc}
\hline Membrane & Nominal thickness $(\mu \mathrm{m})$ & $R_{\mathrm{hf}}\left(\Omega \mathrm{cm}^{2}\right)$ & $i_{x}\left(\mathrm{~mA} \mathrm{~cm}^{-2}\right)$ \\
\hline N112 (6) & 51 & $0.065 \pm 0.005$ & $1.3 \pm 0.2$ \\
NRE212CS (2) & 51 & $0.066 \pm 0.002$ & $1.0 \pm 0.5$ \\
NRE211 (4) & 25 & $0.043 \pm 0.006$ & $2.5 \pm 0.9$ \\
\hline
\end{tabular}

The increase in cell voltage losses for operation under air is calculated as:

$\Delta \eta^{\mathrm{air}}(j)=V_{\text {cell }}^{\mathrm{air}, 0}(j)-V_{\text {cell }}^{\mathrm{air}, n}(j)$

With Eqs. (10), (4) and (5) it follows that:

$\Delta \eta^{\text {air }}(j)=\Delta \eta^{\mathrm{O}_{2}}(j)+\Delta \eta_{\text {transport }}^{\text {air }}(j)-\Delta \eta_{\text {transport }}^{\mathrm{O}_{2}}(j)$

The last two terms on the right hand side of Eq. (13) reflect the increase of the oxygen gain upon cycling.

\subsection{Open circuit voltage (OCV)}

In addition to the cell voltage at finite current density, also the cell voltage at zero current density (OCV) can provide information on degradation. The OCV in a PEMFC is reduced compared to the theoretical $E^{0}$ value by $\Delta E_{\text {mix.pot }}$ due to a mixed potential effect at the Pt cathode involving the oxidation of the Pt surface in the reaction $\mathrm{Pt}+\mathrm{H}_{2} \mathrm{O} \leftrightarrow \mathrm{PtO}^{*}+2 \mathrm{H}^{+}+2 \mathrm{e}\left(E^{0}=0.88 \mathrm{~V}\right.$ versus $\left.\mathrm{RHE}\right)[18,29]$. An additional reduction results from the electrochemical reduction of oxygen that balances the oxidation of hydrogen crossing over from the anode. The latter can be estimated by using Eq. (3) with $j \rightarrow 0$, resulting in:

$\mathrm{OCV}=E^{0}-\Delta E_{\text {mix.pot }}-b \log \frac{i_{x}}{i_{0}\left(p O_{2} / p^{o}\right)^{\gamma}}$

This implies that the OCV depends on the $\mathrm{H}_{2}$ cross-over but also, through $i_{0}$, on the catalyst. Using the proportionality of $i_{0}$ and $i_{\mathrm{m}}$ (Section 3.3) under the given conditions and neglecting changes in $\triangle E_{\text {mix.pot }}$ the $\triangle O C V$ between 0 and $n$ cycles can be approximated by:

$\Delta \mathrm{OCV}=b \log \frac{i_{x}^{0} i_{\mathrm{m}}^{n}}{i_{x}^{n} i_{\mathrm{m}}^{0}}$

\section{Results and discussion}

\subsection{Membrane related properties}

The cells containing membranes with a nominal thickness of $51 \mu \mathrm{m}$ (N112 and N212CS) had an initial ohmic resistance at $80^{\circ} \mathrm{C}$ of about $0.065 \Omega \mathrm{cm}^{2}$ (Table 1 ) and cells with the thinner membranes of $25 \mu \mathrm{m}$ (NRE211) had a resistance of $0.043 \Omega \mathrm{cm}^{2}$. This corresponds to a conductivity value of $0.1 \mathrm{~S} \mathrm{~cm}^{-1}$, in agreement with the expected value. The hf resistance was not related to the type of electrode. Fig. 2 displays the average values measured after each set of 10 load cycles for each type of membrane, showing stable values upon cycling. Data will be used in Section 4.5 to evaluate the contribution to the total cell voltage change.

The $\mathrm{H}_{2}$ cross-over depends strongly on the membrane thickness. Table 1 shows the initial average cross-over measured for values of the current density $i_{x}^{0}$ equivalent to the hydrogen cross-over, referred to 1 bar $\mathrm{H}_{2}$ pressure. Note, that a proportional relation with the thickness is expected if all other properties are the same, which is corroborated by the results in Table 1 . The data correspond well to those reported in the literature $[16,19]$. 


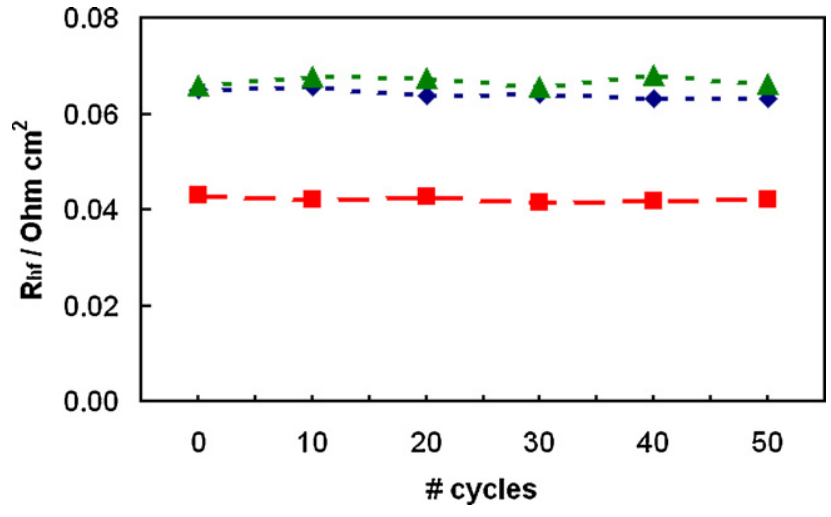

Fig. 2. High frequency resistance of the cells measured after each set of 10 cycles. Average values for each membrane type are shown (( $\downarrow)$ blue: N112,(汭 red: NRE211, $(\boldsymbol{\Lambda})$ green: NRE212CS). (For interpretation of the references to color in this figure legend, the reader is referred to the web version of the article.)

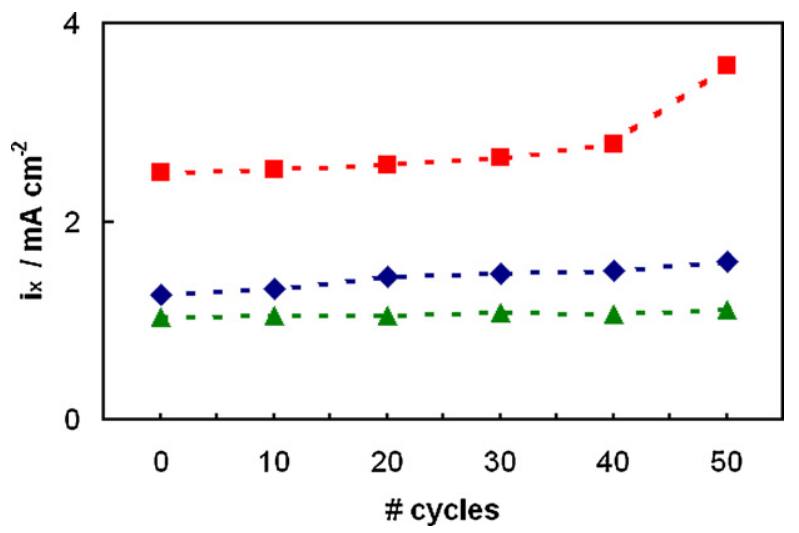

Fig. 3. Cross-over current density measured after each set of 10 cycles. Average

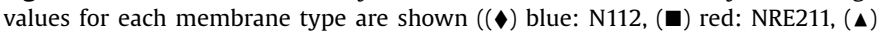
green: NRE212CS). Data refer to 1 bar $\mathrm{H}_{2}$. (For interpretation of the references to color in this figure legend, the reader is referred to the web version of the article.)

The average cross-over current density of each membrane type as measured after each set of cycles is shown in Fig. 3. In almost all MEAs the values were stable. The increase in the average values found for N112 and NRE211 were in both cases due to a single membrane in each set. In one MEA with a NRE211 membrane the initially high value of $3.7 \mathrm{~mA} \mathrm{~cm}^{-2}$ bar $^{-1}$ during the last 10 cycles increased to $7.3 \mathrm{~mA} \mathrm{~cm}^{-2} \mathrm{bar}^{-1}$, and in an MEA with a N112 membrane the cross-over current density showed a steady increase from 1.2 to $2.8 \mathrm{~mA} \mathrm{~cm}^{-2} \mathrm{bar}^{-1}$. The cross-over data will be used in Section 4.2 to obtain kinetic parameters for the cathode and in Section 4.4 to discuss the change in OCV.

\subsection{Cathode kinetic losses}

The initial values of the kinetic parameters for all electrode types are given in Table 2. The initial average ECSA of Hispec 9100 elec-

Table 2

The initial values for ECSA and kinetic parameters at $80^{\circ} \mathrm{C}$. Average values for each electrode type, number of MEAs included in the average in parentheses, are listed with corresponding standard deviation.

\begin{tabular}{lclc}
\hline & Hispec 4000 & Hispec 9100 & Hispec 9100 \\
& $\mathrm{N}: \mathrm{C}=0.7(5)$ & $\mathrm{N}: \mathrm{C}=0.7(2)$ & $\mathrm{N}: \mathrm{C}=0.55(5)$ \\
\hline ECSA $\left(\mathrm{m}^{2} \mathrm{~g}^{-1}\right)$ & $33 \pm 5$ & $66 \pm 6$ & $72 \pm 9$ \\
$i_{\mathrm{s}}\left(\mu \mathrm{Acm}^{-2}\right)$ & $111 \pm 21$ & $99 \pm 24$ & $125 \pm 15$ \\
$i_{\mathrm{m}\left(\mathrm{Ag}^{-1}\right)}$ & $36 \pm 7$ & $65 \pm 19$ & $90 \pm 19$ \\
$b\left(\mathrm{mV} \mathrm{dec}^{-1}\right)$ & $60 \pm 3$ & $59 \pm 6$ & $69 \pm 6$ \\
\hline
\end{tabular}

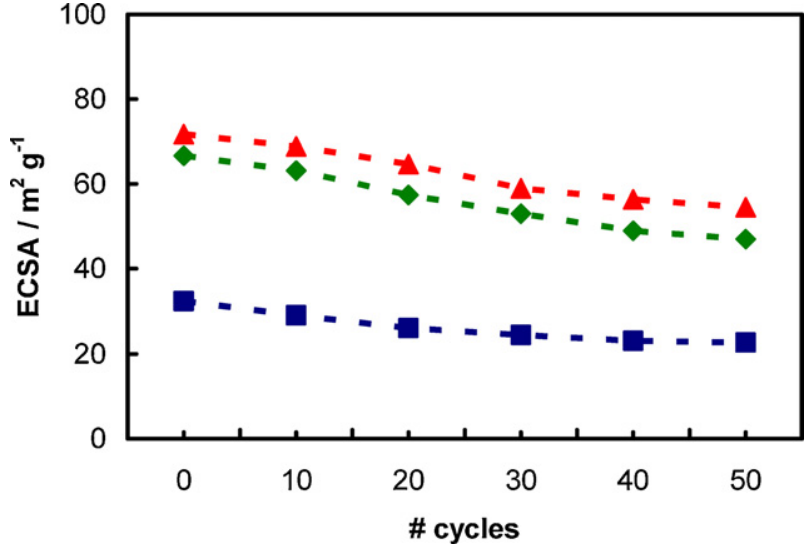

Fig. 4. ECSA values measured after each set of 10 cycles. Average values for the three types of electrodes are shown $((\boldsymbol{\square})$ blue: Hispec $4000, \mathrm{~N}: \mathrm{C}=0.7,(\downarrow)$ green: Hispec $9100, \mathrm{~N}: \mathrm{C}=0.7,(\boldsymbol{\Delta})$ red: Hispec $9100, \mathrm{~N}: \mathrm{C}=0.55$ ). (For interpretation of the references to color in this figure legend, the reader is referred to the web version of the article.)

trodes is about twice as large as of Hispec 4000, in agreement with the smaller particle size of Hispec 9100 (2.8 versus $3.9 \mathrm{~nm}$ according to the supplier) and an improved utilization of the Hispec 9100 [21], that is even enhanced when the Nafion content is decreased from $\mathrm{N}: \mathrm{C}=0.7$ to 0.55 . The ECSA showed a decrease upon cycling (Fig. 4). It was found that after 50 cycles the average ECSA decrease of Hispec 4000 electrodes as well as Hispec 9100 with the higher ratio of $\mathrm{N}: \mathrm{C}=0.7$ was $29 \pm 4 \%$, whereas the Hispec 9100 electrode with $\mathrm{N}: \mathrm{C}=0.55$ only showed $20 \pm 4 \%$ decrease of ECSA. The decrease reported here is similar or slightly lower than the 30\% observed by Lee et al. in similar experiments with electrodes based upon $20 \mathrm{wt} \% \mathrm{Pt} / \mathrm{C}$ from E-TEK [14]. The results are in good agreement with the decrease observed by Ferreira at al. during $500 \mathrm{~h}$ of continuous testing at $\mathrm{OCV}$ and $0.2 \mathrm{~A} \mathrm{~cm}^{-2}$ [5].

The specific activity of Hispec 4000 and Hispec 9100 seems quite similar. As a consequence the mass activity values are substantially smaller for the Hispec 4000 than for the Hispec 9100 electrodes. The values of effective kinetic Tafel slope $b$, also included in Table 2 are close to the theoretical value of $70 \mathrm{mV} \mathrm{dec}^{-1}$.

Fig. 5 shows the average values of $i_{\mathrm{s}}$ and $i_{\mathrm{m}}$ for each electrode type, measured after each set of ten cycles. The mass activity decreases considerably in all cases but the specific activity is more stable, especially in the case of Hispec 9100 with $\mathrm{N}: \mathrm{C}=0.55$. Using Eq. (8) the increase of kinetic losses was estimated to be $22 \mathrm{mV}$ for the Hispec 4000 cathodes, $17 \mathrm{mV}$ for the Hispec 9100 with $\mathrm{N}: \mathrm{C}=0.7$ and $11 \mathrm{mV}$ for the Hispec 9100 with $\mathrm{N}: \mathrm{C}=0.55$. In Section 4.5 this will be compared to the total increase of the cell voltage losses.

\subsection{Protonic resistance of the cathode}

For three Hispec 4000 electrodes, three Hispec 9100 electrodes with $\mathrm{N}: \mathrm{C}=0.55$ and two Hispec 9100 electrode with $\mathrm{N}: \mathrm{C}=0.7$, the protonic resistance $R_{\mathrm{p}}$ was determined. Fig. 6 shows an example of the Nyquist plot obtained with each electrode type. The plot of Hispec $9100 \mathrm{~N}: \mathrm{C}=0.55$ electrode showed the most pronounced $45^{\circ}$ line, indicative of a high $R_{\mathrm{p}}$ value. This is confirmed by plot of the absolute value of $\left(Z_{t}-R_{\mathrm{hf}}\right)$ versus $\omega^{-1 / 2}$, which has the steepest slope for this electrode (Fig. 6b). Note, however that the slope is indicative for $R_{\mathrm{p}} / C_{\mathrm{dl}}$. The higher $C_{\mathrm{dl}}$ in Hispec 9100 electrodes accounts for the fact that Hispec 4000 electrodes and Hispec 9100 electrode with $\mathrm{N}: \mathrm{C}=0.7$ had similar $R_{\mathrm{p}}$ values (Fig. 7) in spite of the difference in slope in Fig. 6b.

The $R_{\mathrm{p}}$ values for Hispec 4000 electrodes and the Hispec 9100 electrodes with the high $\mathrm{N}$ : $\mathrm{C}$ ratio of 0.7 are in agreement with what can be expected on the basis of the thickness (Pt loading) and Nafion 

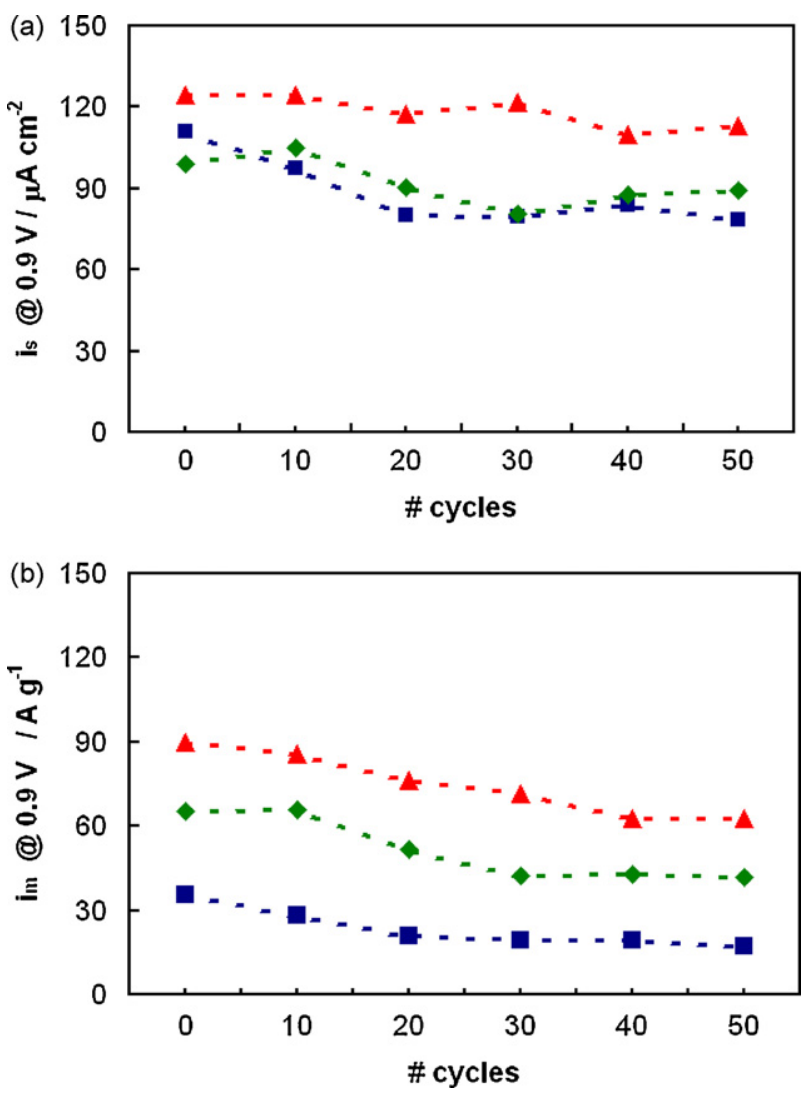

Fig. 5. Average values of the specific (a) and mass activity (b) measured after each set of 10 cycles for each type of electrode $(\boldsymbol{\nabla})$ blue: Hispec $4000, \mathrm{~N}: \mathrm{C}=0.7,(\downarrow)$ green: Hispec 9100, N:C=0.7, (४) red: Hispec 9100, N:C=0.55). (For interpretation of the references to color in this figure legend, the reader is referred to the web version of the article.)

content $[21,30]$, and do not seem to be significantly affected by the load cycles (Fig. 7). The values for the Hispec 9100 electrodes with $\mathrm{N}: \mathrm{C}=0.55$ in Fig. 7 on the other hand are much higher, and seem to decrease with cycling. They also showed more disparity, with standard deviations for the average values of $0.3 \Omega \mathrm{cm}^{2}$ whereas for the electrodes with $\mathrm{N}: \mathrm{C}=0.7$ this was only $0.03 \Omega \mathrm{cm}^{2}$. Both the high values as well as the disparity indicate this type of electrode is non-optimal, i.e. has a too low Nafion content. According to the literature ideal $\mathrm{N}: \mathrm{C}$ ratio for carbon-clack based electrodes is in the order of 0.67 [30].

\subsection{OCV values}

In Fig. 8 the average OCV values $\left(\mathrm{H}_{2} /\right.$ air $)$ measured after each set of ten load cycles for the MEAs with a N112 membrane are shown. It is clear that the OCV shows a tendency to decrease with cycling, but also that the values for MEAs with Hispec 9100 electrodes are higher than for MEAs Hispec 4000 electrodes, in agreement with the higher mass activity of Hispec 9100. Using Eq. (15) and the average initial activity values listed in Table 2 , it can be calculated that the expected difference between, otherwise similar, Hispec 4000 and Hispec 9100 MEAs with $\mathrm{N}: \mathrm{C}=0.7$ and $\mathrm{N}: \mathrm{C}=0.5$ would be 18 and $28 \mathrm{mV}$, respectively. This is in fair agreement with the respective measured differences of 18 and $20 \mathrm{mV}$. After 50 cycles the reduction in the average OCV was 42,22 and $24 \mathrm{mV}$ for Hispec 4000 , Hispec 9100 with $\mathrm{N}: \mathrm{C}=0.7$ and Hispec 9100 with $\mathrm{N}: \mathrm{C}=0.55$ respectively. In part this is due to kinetic contribution, values of which were given at the end of Section 4.2, but there is also an indication of increasing $i_{x}$.
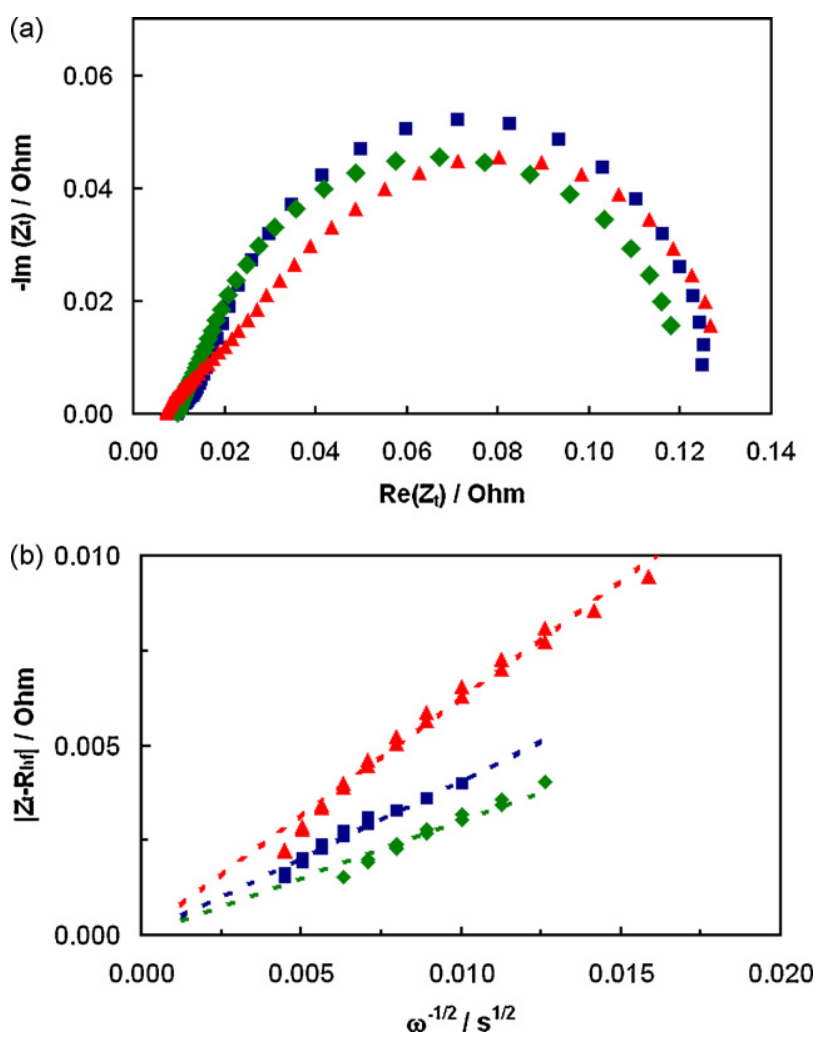

Fig. 6. (a) Nyquist spectra of MEAs with a Hispec $4000 \mathrm{~N}: C=0.7((\mathbf{\square})$ blue), a Hispec $9100 \mathrm{~N}: \mathrm{C}=0.7((\downarrow)$ green) and a Hispec 9100, N:C $=0.55((\Delta)$ red $)$ cathode respectively. (b) $R_{\mathrm{hf}}$ corrected values of $\left|Z_{t}\right|$ plotted versus $\omega^{-1 / 2}$. These points were selected as belonging to the $45^{\circ}$ region of the Nyquist spectrum in (a) and used to fit Eq. (9). The legend is the same as in (a). (For interpretation of the references to color in this figure legend, the reader is referred to the web version of the article.)

Fig. 8 also shows that the OCV depends on the membrane type, and especially its thickness as this determines the $\mathrm{H}_{2}$ cross-over. From Eq. (15) it follows that an increase of the cross-over current density from $i_{x}^{1}$ to $i_{x}^{2}$ corresponds to $\triangle \mathrm{OCV}=b \log \left(i_{x}^{1} / i_{x}^{2}\right)$. On the basis of a 50\% lower thickness alone, the OCV for the NRE211 containing MEAs would have been $21 \mathrm{mV}$ (i.e. $70 \mathrm{mV} \mathrm{dec}^{-1} \times \log (2)$ ) lower than for the a MEA with similar electrodes but having a N112 membrane, in good agreement with the initial observed difference in OCV of $22 \mathrm{mV}$. The decrease in average OCV of NRE211 MEAs

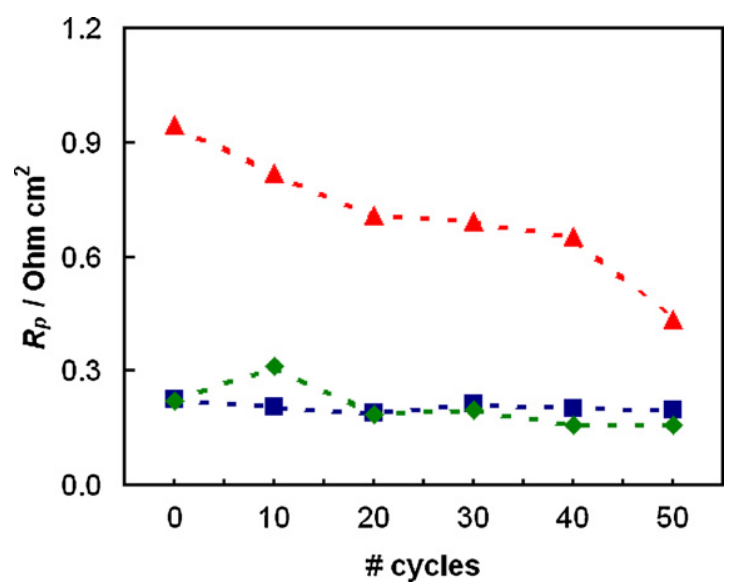

Fig. 7. Averaged $R_{\mathrm{p}}$ values of the cathodes after each set of 10 cycles ( $(\boldsymbol{\square})$ blue: Hispec

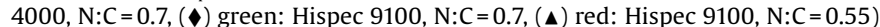
(For interpretation of the references to color in this figure legend, the reader is referred to the web version of the article.) 


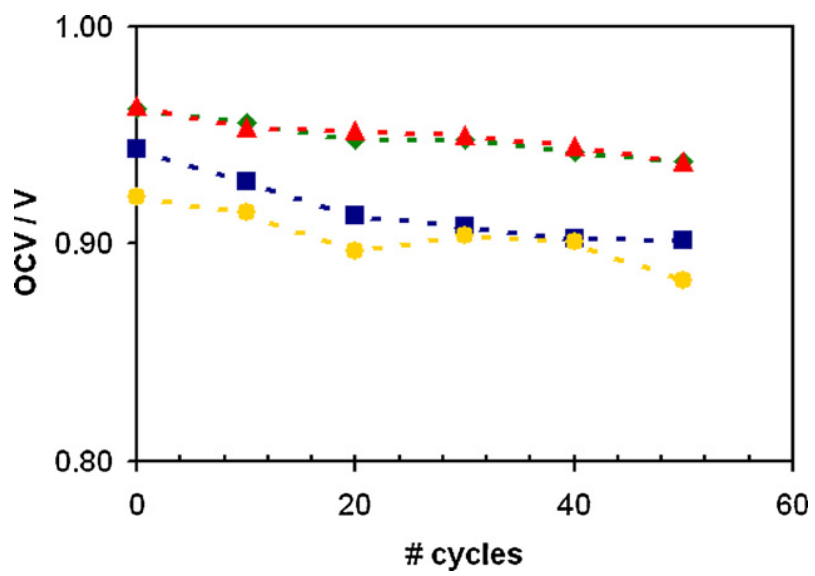

Fig. 8. Average OCV values measured after each set of 10 cycles. Blue ( $\mathbf{\square})$ : Hispec $4000 \mathrm{~N}: \mathrm{C}=0.7, \mathrm{~N} 112$ membrane; $(\diamond)$ green: Hispec 9100, N:C=0.7, N112 membrane;

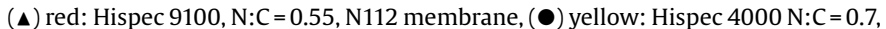
NRE211 membrane. (For interpretation of the references to color in this figure legend, the reader is referred to the web version of the article.)

upon cycling was not as smooth as for the pairs having a Nafion 112 membrane. However, after 50 cycles the average decrease of these MEAs with Hispec 4000 electrode was $38 \mathrm{mV}$, again indicating a contribution from increase of $i_{x}$ as well as decreased mass activity.

\subsection{Changes in the total cell voltage}

The data on changes in membrane and electrode properties presented in Sections 4.1-4.3 can now be quantitatively related to the change in cell voltage upon cycling. This breakdown of the voltage loss is reported here only for a current density of $0.4 \mathrm{Acm}^{-2}$ and is displayed in Fig. 9 as a function of the number of cycles. After 50 cycles the average increase in cell voltage loss for operation under air was 86, 51 and $16 \mathrm{mV}$ for the MEAs with Hispec 4000, Hispec $9100 \mathrm{~N}: \mathrm{C}=0,7$ and Hispec $9100 \mathrm{~N}: \mathrm{C}=0.55$ electrodes, respectively. The differences between these values are larger than the differences in initial performance at $0.4 \mathrm{~A} \mathrm{~cm}^{-2}$ which were $674 \pm 6,683 \pm 3$ and $679 \pm 7 \mathrm{mV}$, respectively.

In agreement with the nearly constant ohmic resistances presented in Section 4.1, the change in ohmic losses $\Delta \eta_{\Omega}$ as given in Eq. (6) is only a small contribution to the increase in cell voltage loss, and in some case even negative. The contribution of the kinetic losses as calculated from Eq. (8) was always positive.

The $\Delta \eta^{\mathrm{O}_{2}}$ (Eq. (10)) seems to be dominated by $\Delta \eta_{\mathrm{ORR}}$, with minor contributions from changes in transport losses. $R_{\mathrm{p}}$ was virtually unchanged in the case of Hispec 4000 and Hispec 9100 with $\mathrm{N}: \mathrm{C}=0.7$. In the case of Hispec $9100 \mathrm{~N}: \mathrm{C}=0.55, R_{\mathrm{p}}$ decreased considerably. The decrease of $R_{\mathrm{p}}$ may be responsible for the $\Delta \eta^{\mathrm{O}_{2}}$ being slightly lower than $\Delta \eta_{\text {ORR }}$ at $n=50$ in the case of Hispec 9100 with $\mathrm{N}: \mathrm{C}=0.55$, i.e. a negative $\Delta \eta_{\text {transport }}^{\mathrm{O}_{2}}$

Fig. 9 shows that the change in oxygen gain, which is according to Eq. (14) the difference between $\Delta \eta^{\text {air }}$ and $\Delta \eta^{\mathrm{O}_{2}}$, was clearly largest in Hispec 4000 electrodes, and smallest in the Hispec 9100 $\mathrm{N}: \mathrm{C}=0.55$ electrodes. The differences observed between the electrodes for $\Delta \eta^{\text {air }}$ can almost completely be ascribed to the change in oxygen gain. The oxygen gain contains contributions from diffusion in the GDL as well as transport in the catalyst layer. Since the GDL used in all MEAs was the same, it may be assumed that the changes in oxygen gain due to the GDL were similar in all MEAs, and that the different behavior observed for the three electrode types must be related to differences in the catalyst layer structure. Fig. 7 showed no change in the $R_{\mathrm{p}}$ of Hispec 4000 . Most likely, a decrease in oxygen permeability caused the larger oxygen gain for Hispec 4000. This decrease in permeability seemed smaller in the case of the Hispec
9100 electrode with the same $\mathrm{N}: \mathrm{C}$ ratio of 0.7 , suggesting that the carbon type may have an effect. Reduction of the ionomer content, as in the Hispec 9100 MEAs with $\mathrm{N}: \mathrm{C}=0.55$, resulted in a much smaller increase in oxygen gain. In this case significant reductions of the $R_{\mathrm{p}}$ were observed, which may have compensated the decrease of permeability. Reduction of $R_{\mathrm{p}}$ indicates either a reduction of the catalyst layer thickness or an increase in effective conductivity of the ionomer [19,21].

Material effects affecting the morphology of the catalyst layer, and hence the transport properties, are carbon corrosion and ionomer instability. In addition ionomer reorganization due to
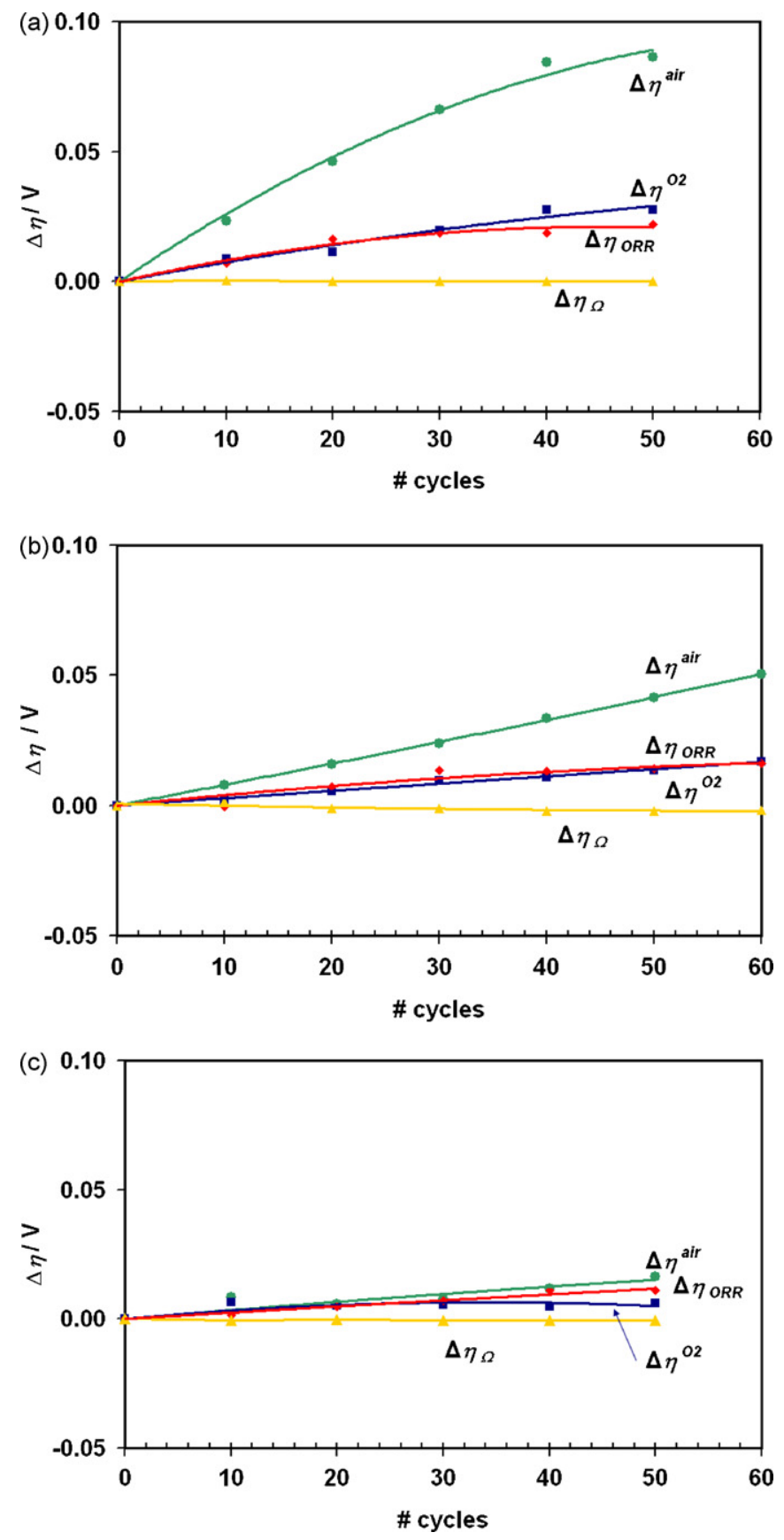

Fig. 9. The average change in cell voltage loss at $0.4 \mathrm{Acm}^{-2}$ when operated under air $\Delta \eta^{\text {air }}((\bullet)$ green $)$, under oxygen $\Delta \eta^{\mathrm{O}_{2}}((\boldsymbol{\nabla})$ blue $)$, as well as $\Delta \eta_{\Omega}((\boldsymbol{\Delta})$ yellow $)$ and $\Delta \eta_{\text {ORR }}((\diamond)$ red). (a) Hispec 4100 electrodes, N:C $=0.7$, (b) Hispec 9100 electrodes, $\mathrm{N}: \mathrm{C}=0.7$ and (c) Hispec 9100 electrodes, $\mathrm{N}: \mathrm{C}=0.55$. (For interpretation of the references to color in this figure legend, the reader is referred to the web version of the article.) 
e.g. swelling and shrinkage cannot be excluded. Ex situ corrosion studies at PEMFC conditions of the carbon materials used as support for the two catalysts types considered here showed similar degradation mechanisms but higher corrosion rates for the material with higher surface area [31]. The exact dependence of catalyst layer degradation on carbon type and content as well as on ionomer content requires further investigation but the apparently large reduction of the permeability suggests that increased hydrophilicity due to carbon corrosion plays a significant role.

It should also be noted that the cell voltages were obtained from $V-j$ characteristics and therefore are expected to reflect mostly irreversible changes in the MEA. Still it cannot be excluded that some reversible effects, i.e. related to water content, are included in the $V-j$ characteristics. However, the fact that most data given here are based upon measurements of several MEA will lead to cancellation of incidental effects, such as formation of water droplets.

In all cases the performance seemed more stable, i.e. a smaller $\Delta \eta^{\text {air }}$, than in the similar test by Lee et al. [14]. However, the MEA studied with $\mathrm{H}_{2}$ /air purging under OCV periods in that work showed appreciable membrane degradation. It is not clear why this was not observed in any of 12 MEAs studied here (see also below). However, in a recent paper Kundu et al. pointed out the mitigating effect of a microporous layer in the GDL on the membrane degradation [32]. The MEAs in this work contained such a layer, whereas those in Ref. [14] did not.

(a)

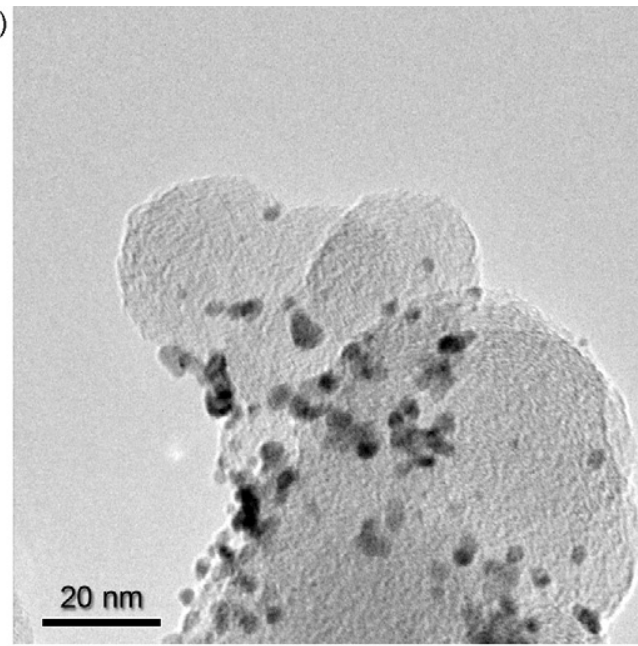

(c)

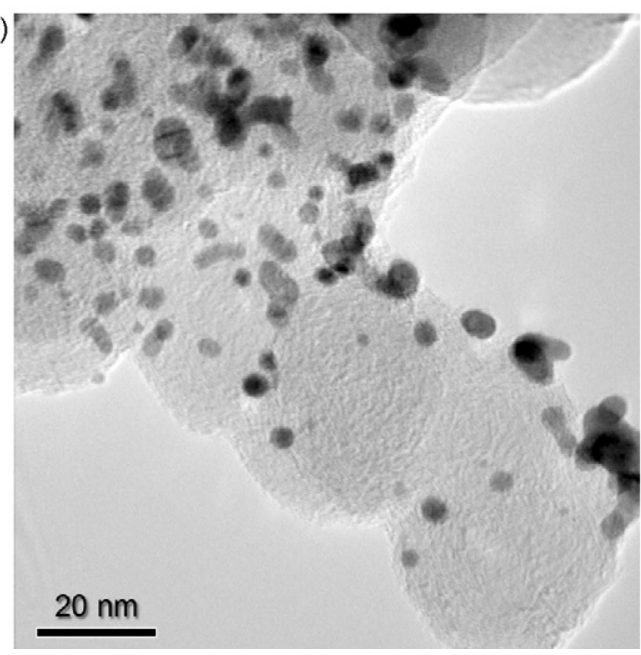

Table 3

Estimated thickness of membranes and electrodes from post-test SEM micrographs.

\begin{tabular}{lllll}
\hline Membrane & Electrodes & $\begin{array}{l}\text { Thickness } \\
\text { membrane }(\mu \mathrm{m})\end{array}$ & $\begin{array}{l}\text { Thickness } \\
\text { anode }(\mu \mathrm{m})\end{array}$ & $\begin{array}{l}\text { Thickness } \\
\text { cathode }(\mu \mathrm{m})\end{array}$ \\
\hline N112 & $\begin{array}{l}\text { Hispec } 4000 \\
\mathrm{~N}: \mathrm{C}=0.7\end{array}$ & 41 & 13 & 15 \\
N112 & $\begin{array}{l}\text { Hispec } 9100 \\
\mathrm{~N}: \mathrm{C}=0.55\end{array}$ & 44 & 10 & 7 \\
NRE 211 & $\begin{array}{l}\text { Hispec } 4000 \\
\mathrm{~N}: \mathrm{C}=0.7\end{array}$ & 25 & 11 & 10 \\
NRE 211 & $\begin{array}{l}\text { Hispec } 9100 \\
\mathrm{~N}: \mathrm{C}=0.55\end{array}$ & 23 & 7 & 5 \\
NRE212 CS & $\begin{array}{l}\text { Hispec } 9100 \\
\mathrm{~N}: \mathrm{C}=0.55\end{array}$ & 56 & 8 & 13 \\
\hline
\end{tabular}

\subsection{Post test analysis}

Five of the tested MEAs were analyzed by SEM. The back scatter-image enabled a clear identification of the membrane and electrodes and an estimation of the respective thicknesses could be made (Table 3). The thicknesses of the membranes are quite close to the nominal values specified in Table 1, except in the case of N112 which seemed significantly thinner. However, the large reduction for Nafion 112 to $15 \mu \mathrm{m}$ as reported by Lee at al. [14] was not found. In all other cases a slight reduction may have occurred, except the NRE212CS membrane which in the micrograph seemed actually thicker than specified. No significant effect of the type of electrode

(b)

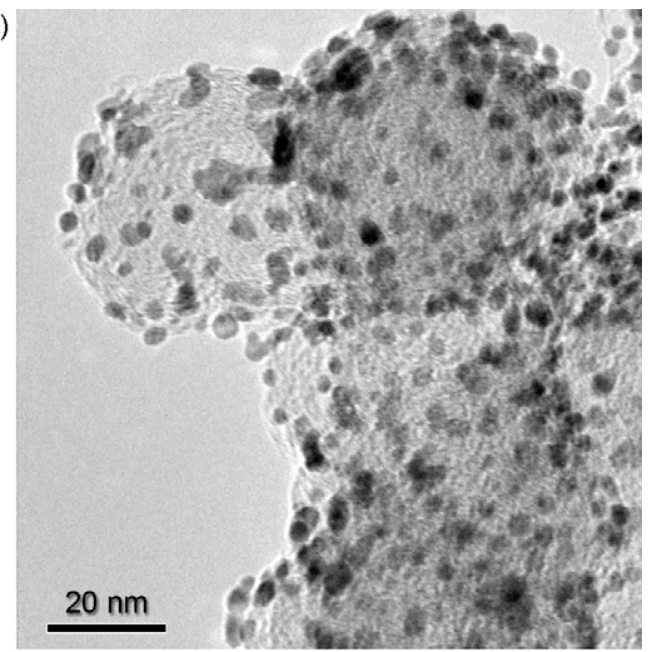

(d)

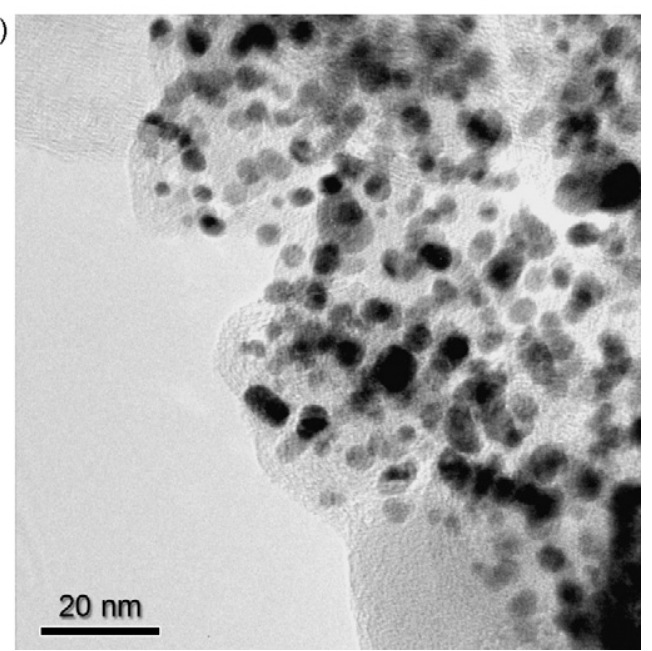

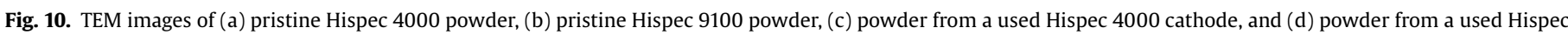
9100 cathode. 
on the membrane thickness seems to be present. The thickness of the electrodes varied somewhat, but no significant thinning was observed.

The TEM analysis (Fig. 10) shows only a slight increase in Pt particle size and onset of particle agglomeration in both type of electrodes, again in contrast with the significant Pt particle growth observed by Lee at al. [14]. The observed increase in particle size seems in agreement with the observed decrease in ECSA (Fig. 4) of $29 \%$ and $20 \%$ for Hispec 4000 and Hispec $9100 \mathrm{~N}: \mathrm{C}=0.55$, respectively. The most significant change in this sample was not the Pt particle growth but the fact that the sample shows some regions of carbon that contain no Pt (bottom and upper left hand corner of Fig. 10d), whereas the pristine sample showed a very even distribution of Pt over the carbon surface (Fig. 10b). This suggests that Pt dissolved or came off the carbon support during this test.

\section{Conclusions}

A detailed analysis of the changes in performance, kinetic and transport properties of the electrodes and membrane properties upon of load-on/off cycles of several MEAs was made. Regardless of the electrode type, the kinetic activity showed a decrease, most of all due to a gradual loss of active surface area. The transport losses on the other hand were very sensitive to the electrode type: they were stable for electrodes based upon Hispec 9100 catalyst powder with a low ionomer content, whereas they increased with ionomer content and also were larger for Hispec 4000 electrodes, which have a different carbon support. This result was attributed to changes in hydrophilicity of the electrodes being dependent on the type of carbon support and the ionomer content of the electrode. The membrane resistance was not affected by the cycling although in some cases a significant increase in $\mathrm{H}_{2}$ cross-over was measured. The result was that the Hispec 4000 MEAs showed a substantial voltage decline, whereas the performance of Hispec 9100 with $\mathrm{N}: \mathrm{C}=0.55$ MEAs remained quite stable.

With regard to the test procedure it must be noted that the conditions give some qualitative indication on durability, but that more prolonged cycling and use of alternative load-profiles is required to quantitatively predict durability. However, the results suggest that increased transport losses can give a substantial contribution to the voltage decay of PEMFCs and therefore it is recommended to include degradation of the catalyst layer explicitly into accelerated stress tests.

\section{Acknowledgements}

The authors wish to thank H.C.D. Smit and M. Aalberts (ECN) for MEA preparation, C.M. Roos (ECN) for SEM characterization of MEAs and M. Prieto (JRC) for the preparation of TEM samples.

\section{References}

[1] M.F. Mathias, R. Makharia, H.A. Gasteiger, J.J. Conley, T.J. Fuller, C.J. Gittleman, S.S. Kocha, D.P. Miller, C.K. Mittelsteadt, T. Xie, S.G. Yan, P.T. Yu, Electrochem. Soc.-Interface 14 (2005) 24-35 (Fall).

[2] N. Garland, T. Benjamin, J. Kopasz, ECS Trans. 11 (2007) 923-931.

[3] R. Borup, J. Meyers, B. Pivovar, Y.S. Kim, R. Mukundan, N. Garland, D. Myers, M. Wilson, F. Garzon, D. Wood, P. Zelenay, K. More, K. Stroh, T. Zawodzinski, J. Boncella, J.E. McGrath, M. Inaba, K. Miyatake, M. Hori, K. Ota, Z. Ogumi, S. Miyata, A. Nishikata, Z. Siroma, Y. Uchimoto, K. Yasuda, K.I. Kimijima, N. Iwashita, Chem. Rev. 107 (2007) 3904-3951.

[4] F.A. de Bruijn, V.A.T. Dam, G.J.M. Janssen, Fuel Cells 8 (2008) 3-22.

[5] P.J. Ferreira, G.J. la O', Y. Shao-Horn, D. Morgan, R. Makharia, S. Kocha, H.A Gasteiger, J. Electrochem. Soc. 152 (2005) A2256-A2271.

[6] M. Aoki, H. Uchida, M. Watanabe, Electrochem. Commun. 7 (2005) 1434-1438.

[7] V.O. Mittal, H.R. Kunz, J.M. Fenton, J. Electrochem. Soc. 154 (2007) B652-B656.

[8] V.O. Mittal, H.R. Kunz, J.M. Fenton, J. Electrochem. Soc. 153 (2006) A1755-A1759.

[9] V.O. Mittal, H.R. Kunz, J.M. Fenton, Electrochem. Solid-State Lett. 9 (2006) A299-A302.

[10] H. Liu, H.A. Gasteiger, A.B. LaConti, J. Zhang, ECS Trans. 1 (2006) 283-293.

[11] E. Guilminot, A. Corcella, M. Chatenet, F. Maillard, F. Charlot, G. Berthome, C. Iojoiu, J.Y. Sanchez, E. Rossinot, E. Claude, J. Electrochem. Soc. 154 (2007) B1106-B1114.

[12] S.J.C. Cleghorn, D.K. Mayfield, D.A. Moore, J.C. Moore, G. Rusch, T.W. Sherman, N. Sisofo, U. Beuscher, J. Power Sources 158 (2006) 4-455.

[13] J. Xie, D.L. Wood, D.M. Wayne, T.A. Zawodzinski, P. Atanassov, R.L. Borup, J. Electrochem. Soc. 152 (2005) A104-A113.

[14] S.Y. Lee, E. Cho, J.H. Lee, H.J. Kim, T.H. Lim, I.H. Oh, J. Won, J. Electrochem. Soc. 154 (2007) B194-B200.

[15] C.A. Reiser, L. Bregoli, T.W. Patterson, J.S. Yi, J.D. Yang, M.L. Perry, T.D. Jarvi, Electrochem. Solid-State Lett. 8 (2005) A273-A276.

[16] H.A. Gasteiger, J.E. Panels, S.G. Yan, J. Power Sources 127 (2004) 162-171.

[17] K.C. Neyerlin, W. Gu, J. Jorne, H.A. Gasteiger, J. Electrochem. Soc. 154 (2007) B631-B635.

[18] J. Zhang, Y. Tang, C. Song, J. Zhang, H. Wang, J. Power Sources 163 (2006) 532-537.

[19] H.A. Gasteiger, W. Gu, R. Makharia, M.F. Mathias, B. Sompalli, in: W. Vielstich, H.A. Gasteiger, A. Lamm (Eds.), Handbook of Fuel Cells-Fundamentals, Technology and Applications, vol. 3, John Wiley and Sons, Chichester, UK, 2003, pp. 593-610.

[20] S.S. Kocha, in: W. Vielstich, H.A. Gasteiger, A. Lamm (Eds.), Handbook of Fuel Cells-Fundamentals, Technology and Applications, vol. 3, John Wiley and Sons, Chichester, UK, 2003, pp. 538-565.

[21] G.J.M. Janssen, E.F. Sitters, J. Power Sources 171 (2007) 8-17.

[22] M. Eikerling, A.A. Kornyshev, J. Electroanal. Chem. 453 (1998) 89-106.

[23] M.L. Perry, J. Newman, E.J. Cairns, J. Electrochem. Soc. 145 (1998) 5-15.

[24] T.E. Springer, M.S. Wilson, S. Gottesfeld, J. Electrochem. Soc. 140 (1993) 3513-3526.

[25] K.C. Neyerlin, W. Gu, J. Jorne, H.A. Gasteiger, J. Electrochem. Soc. 153 (2006) A1955-A1963.

[26] M. Eikerling, A.A. Kornyshev, J. Electroanal. Chem. 475 (1999) 107-123.

[27] M.C. Lefebvre, R.B. Martin, P.G. Pickup, Electrochem. Solid-State Lett. 2 (1999) 259-261.

[28] R. Makharia, M.F. Mathias, D.R. Baker, J. Electrochem. Soc. 152 (2005) A970-A977.

[29] J.P. Hoare, J. Electrochem. Soc. 109 (1962) 858-865.

[30] H.A. Gasteiger, S.S. Kocha, B. Sompalli, F.T. Wagner, Appl. Catal. B: Environ. 56 (2005) 9-35.

[31] S.C. Ball, S.L. Hudson, D. Thompsett, B. Theobald, J. Power Sources 171 (2007), pp. 18-15.

[32] S. Kundu, K. Karan, M. Fowler, L.C. Simon, B. Peppley, E. Halliop, J. Power Sources 179 (2008) 693-699. 